T II E

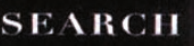
Racing SEARCII to the гок Beginning тие
of the origer
Road $\quad$ or Robert A. Weinberg

\section{Racing to the Beginning of the Road}

\section{THE SEARCH FOR THE ORIGIN OF CANCER}

\author{
by Robert $A$. Weinberg \\ Harmony Books \\ New York, New York \\ ISBN: 0-517-59118-9, 1996, \$27.50
}

\section{Reviewed By DREW M. PARdoll \\ Department of Oncology}

Johns Hopkins University School of Medicine

720 Rutland Avenue/Ross 364

Baltimore, Maryland 21205, USA

In his new book about the discovery of the origins of cancer, Racing to the Beginning of the Road, Robert Weinberg endeavors to walk a literary tightrope. Writing from the standpoint of one of the central players in the oncogene field, Weinberg attempts to weave scientific history with the psychosocial dramas played out among some of the diverse personalities that drove the theoretical and experimental development of modern cancer research. Overemphasis on pure science would make the book too dry. Excessive attention to personalities and politics would damage the credibility of the scientific history and, with it, the message that the data must ultimately carry the day. Overall, Weinberg does a good job of maintaining his balance and demonstrating that the process by which cancer researchers put the picture together is as interesting as the picture itself.

The story begins with one of the infamous detours in cancer research, driven by the arrogant Nobelist, Otto Warburg. In describing how Warburg used his overbearing self-confident style to divert legions of scientists into "confirming" his energy metabolism theory of cancer, Weinberg introduces a recurrent theme that neither big stature, big voice nor big resources guarantee the ultimate veracity or importance of the work. Most of the heroes in the carcinogenesis story, including Weinberg, were relatively junior scientists with relatively small labs at the time of their most influential insights and discoveries. They are presented as quite mortal, with insecurities and idiosyncrasies just like the rest of us. One of the early heroes was a distant cousin of Weinberg's, Ernst Wynder, who battled colleagues, bosses and tobacco companies in his crusade to show that carcinogens in cigarette smoke were a major cause of lung cancer.

The topics accorded the greatest attention are chemical carcinogenesis, RNA tumor viruses and oncogenes. Weinberg describes the rivalry that developed between the chemical carcinogenesis crowd and the viral carcinogenesis crowd. Initially, the two theories were perceived as mutually exclusive; therefore, if one group was right, the other group had to be wrong. Ultimately, both camps turned out to be partly correct and Weinberg does a nifty job telling the story of how key discoveries eventually melded elements of both theories into a coherent picture. He also uses this slice of carcinogenesis history to demonstrate the manner in which some lines of research can become mired in a scientific swamp while others progress to the next level. The chemical carcinogenesis group got stuck in a rut because they never established clean techniques to determine which of the many carcinogen targets within the cell were relevant to the ultimate transformation process. Even Bruce Ames' elegant genetic evidence that mutagen = carcinogen could not lead them out of the junk heap of biochemical phenomenology. In contrast, the rapid advances in molecular biology provided the tumor virus group with sleek vehicles to transport them ever closer to the central events of transformation.
It is at this point that Weinberg's own contribution to the story enters Stage Right. The National Cancer Institute was pouring outrageous amounts of money into the Special Virus Cancer Program to provide opulent support for a few preordained labs to hunt down viruses that could be causing human cancer. Weinberg can barely contain his disdain for this centrally administered big science approach and some of the opportunists that benefited from it. Clearly the viral carcinogenesis group needed a course adjustment once Nobelists Harold Varmus (now Director of the National Institutes of Health) and J. Michael Bishop showed that oncogenes didn't need a virus to carry them into cells - they were sitting in the genome all along as protooncogenes. Weinberg describes his idea to use the transfection assay to identify a real activated human oncogene as the only truly original idea he ever had. I doubt this to be the case but there is nothing fake about his modesty in describing the fits and starts characterizing his fledgling laboratory's four-year effort to discover the first mutated endogenous oncogene in a human cancer. This endeavor had plenty of personal intrigue to go along with the scientific intrigue - a superstar who came out of nowhere only to be discredited for probable fraud, a multigroup competition revolving around the same cancer line and strategic alliances to gain precious weeks in the race. And then . . . finally . . . eureka! a single point mutation elevating the ras oncogene and this young investigator from obscurity to notoriety. Weinberg engages the reader effectively while refraining from turning the book into a spy novel. As satisfying as the identification of mutant ras was, we now know that activated oncogenes are only one piece of the oncogenesis picture. There is limited attention paid to tumor suppressor genes (one chapter) and only passing mention of the discovery of mutator genes, stories full of their own intrigues. Other more recent discoveries such as the inactivation of tumor suppressor genes by DNA tumor virus oncogenes or the role of the p53 pathway as genome guardian escape mention altogether.

While one could therefore compare Racing to the Beginning of the Road to a New Yorker's map of the United States, Weinberg nonetheless does an admirable job of mixing personal and historical perspective while conveying the thrill of the chase. I must admit that once I started reading, I couldn't put it down. 